\title{
CDISC SDTM Nutrition Findings About Test Code Terminology
}

National Cancer Institute

\section{Source}

National Cancer Institute. CDISC SDTM Nutrition Findings About Test Code Terminology. NCI Thesaurus. Code C154685.

Terminology associated with the nutrition findings about test code codelist of the Clinical Data Interchange Standards Consortium (CDISC) Study Data Tabulation Model (SDT M). 